\title{
THE EFFECTS OF SELF-REGULATED LEARNING STRATEGIES ON PRESCHOOL CHILDREN'S SELF-EFFICACY AND PERFORMANCE IN EARLY WRITING
}

\author{
Siew Siew Kim ${ }^{1}$, Mariani Md. Nor ${ }^{2}$ \\ Faculty of Education of University of Malaya, Kuala Lumpur, Malaysia \\ siewsiewkim@yahoo.com ${ }^{1}$; marianin@um.edu.my ${ }^{2}$
}

First draft received: 24 Oct 2018 Date Accepted: 24 Dec 2018 Final proof received: 5 Feb 2019

\begin{tabular}{l} 
Abstract \\
To enhance the will and the skills to express thoughts explicitly and effectively in early writing among \\
preschool children, self-regulated learning (SRL) was suggested for preschool children as one of the \\
effective learning approaches. This quasi-experimental study involved seventy-five preschool children $(5-6$ \\
years old) from two public preschools in Selangor, Malaysia. This study investigated the effects of $S R L$ \\
strategies on early writing self-efficacy and early writing performance among preschool children. Interview \\
data was engaged and supported the quantitative result to obtain a deep insight of the findings. Two-way \\
Repeated Measure ANCOVA was employed and confirmed the effectiveness of self-regulated learning \\
intervention with an interaction effect between the test and group for early writing self-efficacy being \\
statistically significant $(F(1,72)=12.665 ; p=0.001, \square 2=0.150)$, with Cohen's $d=0.84 ;$ and early writing \\
performance statistically significant $(F(1,72)=110.801 ; p<0.001, \square 2=0.606)$, with Cohen's $d=2.84$. The \\
result also confirmed that self-monitoring and controlling $(F(5,69)=17.934, p<0.001)$, with an adjusted \\
$\mathrm{R}^{2}=0.534$, was a strong predictor for early writing self-efficacy, and planning and goal setting (F(5, 69$)=$ \\
$12.706, p<0.001)$, with an adjusted $\mathrm{R}^{2}=0.442$, were a strong predictor for early writing performance. \\
Eleven self-regulated learning strategies used emerged from the interviews' data pertaining to different \\
contexts. According to the participant children, planning and goal setting, self-monitoring, and self- \\
evaluation were the strategies that will assure their writing quality. These responses supported the results \\
produced by the quantitative data. The findings of this research provide a useful insight into early writing \\
and self-regulated learning instructions in the Malaysian preschool context. \\
Keywords: early writing; preschool; self-efficacy; self-regulated learning \\
\hline \hline
\end{tabular}

\section{INTRODUCTION}

Research in education indicates that self-regulated learning (SRL) is crucial for young learners' learning process; it enhances their academic performance and learning motivation (Anam \& Stracke, 2016; Dent \& Koenka, 2015; Mega, Ronconi, \& Beni, 2014; PinoPasternak, Basilio, \& Whitebread, 2014). Characteristics of SRL involve intrinsic motivation and autonomous learning to help learners to achieve their goals in any learning situation (Zimmerman, 2013; Panadero, 2017). In Malaysia, students are expected to learn how to learn and how to take responsibilities for making their learning more constructive and successful. Taking responsibility and controlling their learning has been highlighted in the Malaysian education system (MOE, 2015; MOE, 2017). Although early academic performance skills such as numeracy and literacy skills are essential for school success, children's self-regulation abilities, including the ability to follow instructions, focus on materials presented to them, and demonstrate self-control, are important predictors of their later academic achievement (Diamond, 2016; McClelland, Acock, Piccinin, Rhea, \& Stallings, 2013). Thus, aligned with the expectation of the Malaysian Education Blueprint (MOE, 2015), preschool education in Malaysia aims to prepare preschool children to proceed their formal education with various competencies and skills, including literacy skills, thinking skills, problem solving skills as well as self-regulating skills (MOE, 2017). By engaging SRL strategies, preschool children learn how to take initiative in monitoring their learning strategies and place, evaluate their learning, and progress to perform better. Although research suggests that children in their very young age can and do engage in activities to selfregulate their learning process (Pino-Pasternak, Basilio, \& Whitebread, 2014; Whitebread \& Basilio, 2012), most of the local research in Malaysia is still not enough to provide a better understanding about the principles of 
self-regulation generalised across contexts like age group, subjects, and there is scarcity of evidence documenting the use of SRL strategies among younger children, aged from five to six years old in Malaysia ( $\mathrm{Ng}$ \& Yeo, 2014).

In Malaysia, early writing is part of literacy and language development. According to Malaysia's national preschool school curriculum, early writing emphasises not only mechanical or orthography skills; it also emphasises how preschool children learn how to express their message, how to form or make marks on the page, and how to represent sounds within this message (MOE, 2017). Therefore, self-efficacy and SRL strategies are considered key processes that will influence children's early writing process and performance (Bulut, 2017; Hutchinson, 2013). Unfortunately, preschool writing instruction including in Malaysia, is more focused on procedural knowledge than discursive processes (Bingham, Quinn, \& Gerde, 2017; Hall, Simpson, Gerde, Bingham, \& Pendergast, 2015; Hall, Simpson, Guo, \& Wang, 2015; Ng \& Yeo, 2014; Puranik, Al Otaiba, Sidler, \& Greulich, 2014; Samah, Majzub, \& Mahamod, 2015). Teachers place a great emphasis on teaching handwriting skills in class and they do not have a specific approach in teaching writing; instead, they often use copying and drilling as the main strategies in teaching writing. If children learnt and excelled in copying words and handwriting, but not sharing ideas in writing, it can cause an imbalance development of literacy for children. In addition, $\mathrm{Ng}$ \& Yeo (2014) found that preschool teachers in Malaysia place very little focus on developing interest and selfefficacy in early writing. Lacking motivation in literacy will develop lower self-concept and efficacy beliefs in literacy (Anam \& Stracke, 2016; Bulut, 2017). These imply that teaching writing for young children in Malaysia remained unclear. In echoing the above challenges, SRL which emphasises autonomy and own control is recommended to be integrated in early writing instruction.

Writing is a complex, demanding process for both novice and expert writers. Educational research identified key processes of SRL, including goal setting, self-efficacy, metacognitive monitoring, effort and resource management, which contributed to positive outcomes in academic achievement including writing (White \& DiBenedetto, 2015; Zimmerman \& Risemberg, 1997). For example, young children can use SRL strategies to help them in planning ideas, constructing phrases or sentences and revising ideas (Hayes \& Olinghouse, 2015).

Employing SRL in early writing does not only support the writing skills, it also enhances motivational processes and supports long-term writing attitude. According to Bandura's social cognitive theory (Bandura, 2012), self-efficacy is defined as one's belief about one's capabilities to complete a specific task. The beliefs that individuals hold about their abilities influence the amount of effort put into a task, willingness to complete activities, and the ability to persist when facing difficulties. Through SRL, children learn how to plan, seek information and social help, and monitor their writing process; these skills enhance their self-efficacy towards writing. When children positively perceive their writing abilities, they put more effort into their learning processes. Better performance resulting from greater effort will enhance children's self-efficacy. This reciprocal process is important in learning as it influences people's decisions, determining how far they are willing to go, and how hard they are willing or able to push themselves to optimise the chances of positive outcomes (Bandura, 2012).

\section{METHOD}

The current study employed a quasi-experimental design to examine the effectiveness of SRL strategies in improving 5-6 year-old children's self-efficacy and performance in early writing. The strong predictor of SRL strategies on early writing self-efficacy and performance were determined in this study. Participants for experimental and control groups were randomly assigned. The experimental group was instructed in early writing by integrating SRL intervention, which lasted approximately four months. A control group was instructed using the traditional approach.

\section{Participants}

The study sample consisted of seventy-five preschool children, enrolled in two public preschools of Selangor. There were 37 samples in the experimental group and 38 in the control group, respectively. All demographic variables were analysed and compared between experimental and control groups using independent $t$ test and chi square test. Results indicated that data was normally distributed and homogenous. Both groups had similar characteristics in terms of gender, schooling experiences, and language used at home. In addition, prior to data analysis, all scales and subscales in early writing performance and use of self-regulated strategies were tested between the two schools to identify the homogeneity of both schools. Results indicated that both schools were significantly different in all variables, with $p<0.05$. Therefore, the factor of school was removed from the all the results performed in this study to reduce bias. Repeated Measure Analysis of Covariance was suggested for the analysis where the factor of "school" is considered a covariate through the study.

\section{Instruments}

In this study, the Self-Regulation Strategies for Early Writing-Observation Form (SRSEWOF) and the SelfEfficacy Scale of Early Writing (SESEW) were used as the data collection tools. SRSEWOF was adapted from the instrument developed by Demirtas (2013) and closely tied to early writing for preschool children. It was reorganised on the basis of the theories propounded by Zimmerman \& Schunk (2012), with the conceptual framework of the current study and important literature review of SRL and early writing (Metallidaou, 2010; Panadero, 2017; Teng \& Zhang, 2016; Whitebread, et al., 2009). A pool of approximately twenty-six 
statements across five dimensions representing various SRL strategies in early writing was finalised for this current study. Face and content validation of this instrument was done by related areas' experts and practitioners. The overall Cronbach's Reliability CoEfficiency was found at 0.966 . An instrument for early writing self-efficacy (SESEW) was developed. There were two constructs and eight items total in the instrument. This instrument was developed based on the ideas from Kim, \& Lorsbach's study (2005), where children's self-efficacy was assessed from the perspectives of teachers through observable behaviours statements. The internal consistency and reliability of SESEW was tested and was found at coefficient alpha $=0.848$.

To assess the early writing performance of preschool children, Early Writing Performance Scale (EWPS), was developed based on three aspects: (i) content, (ii) children's mechanical writing skills, and (iii) overall writing quality. This scale was developed according to the Learning Standards and Performance
Standards in the Malaysian National Preschool Standard-Based Curriculum and Assessment Document (MOE, 2017). This developed scale was validated by three experts in curriculum development and early literacy in early childhood education in Malaysia. Changes were made according to their comments and feedback.

\section{SRL Intervention Programme}

The transfer of SRL strategies to preschool children was adapted to the specific requirements of five- to six-yearold children's learning abilities. All the SRL strategies in the intervention were arranged into ten units and closely tied to the early writing process. During the intervention, children were provided with sufficient opportunities and a platform to exercise the strategies in every intervention session. Detailed lesson plans and supporting materials were used to train the children to use SRL strategies in early writing. The structure and content of the intervention for the children are shown in Table 1.

Table 1. Overview of the Self-Regulated Learning Intervention

\begin{tabular}{|c|c|c|}
\hline Unit & SRL Content & Training Goals \\
\hline Introduction & Knowledge and importance of SRL & Be aware of and understand SRL strategies \\
\hline Goal setting & Goal Setting & $\begin{array}{l}\text { Understand the importance of realistic goal-setting } \\
\text { Learn how to set individual goals }\end{array}$ \\
\hline Plan my writing & Planning (I) & Use drawing to generate ideas \\
\hline Plan my writing & Planning (II) & $\begin{array}{l}\text { Pick up the ideas from drawing } \\
\text { Put ideas into text }\end{array}$ \\
\hline Elaborate my ideas & Planning (III) & Use Bubble Map to generate ideas \\
\hline I can write & Self-monitoring and controlling & $\begin{array}{l}\text { Be aware of the importance of self-monitoring } \\
\text { Follow the created Early Writing Rules }\end{array}$ \\
\hline Work place & Environmental controlling & Choose and restructure own working place \\
\hline I need help & Seeking social help and information & $\begin{array}{l}\text { Be aware of social help: peer/ teacher/ adult } \\
\text { Know how to use resources }\end{array}$ \\
\hline I can do it & Managing Attention and effort & $\begin{array}{l}\text { Control of distraction (negative thought, noise, } \\
\text { temptation) }\end{array}$ \\
\hline Checked! & Self-reflection & $\begin{array}{l}\text { Encourage reflectivity } \\
\text { Use self-checklist }\end{array}$ \\
\hline
\end{tabular}

\section{RESULTS AND DISCUSSION}

Results related to the level of early writing self-efficacy, early writing performance and the use of SRL strategies before and after intervention; and the effectiveness of $\mathrm{SRL}$ intervention are highlighted as below:

The level of early writing performance among preschool children before and after intervention Early writing self-efficacy in this study refers to two main constructs, confidence and persistence in approaching tasks and beliefs. There were eight items in the instrument and the four point Likert Scale of SESEW ranged from: 1- not like the child, 2- not too much like the child, 3- somewhat like the child, 4- like the child. The level of early writing self-efficacy was categorised into low, moderate, and elevated levels based on results of total scores of the instrument.
Table 2 shows that early writing self-efficacy for both groups were at a moderate level before intervention. Generally, they had positive beliefs towards writing tasks. However, when they were faced with a new and challenging writing task, they lacked confidence and persistency in moving forward. This finding was consistent with some studies done in Malaysia in a different context (Jalaluddin, 2013; Ng \& Yeo, 2014), showing that students in Malaysia always hesitate to write and do not finish their writing task because they think that writing is too difficult. Lacking persistency and effort in completing their writing task caused the low achievement in writing. 
Table 2. Descriptive Statistics of Early Writing Self-Efficacy for Experimental ( $N=37$ ) and Control ( $N=38$ ) Groups

\begin{tabular}{llcccccc}
\hline \multirow{2}{*}{ Constructs } & \multirow{2}{*}{ Group } & Pre-test & \multicolumn{3}{c}{ Post-test } \\
\cline { 3 - 8 } & & $M$ & $S D$ & $M d n$ & \multicolumn{3}{c}{ Mdn } \\
\hline Confidence \& & Experimental & 2.34 & 0.75 & 2.16 & 3.24 & 0.64 & 3.17 \\
Persistence & Control & 2.47 & 0.63 & 2.25 & 3.03 & 0.72 & 3.00 \\
\hline Beliefs & Experimental & 2.92 & 0.51 & 3.00 & 3.35 & 0.59 & 3.50 \\
& Control & 2.50 & 0.75 & 2.50 & 2.38 & 0.93 & 2.25 \\
\hline Overall & Experimental & 19.89 & 5.04 & 19.00 & 26.14 & 4.66 & 25.00 \\
& Control & 19.84 & 3.49 & 19.50 & 22.92 & 4.63 & 22.50 \\
\hline
\end{tabular}

Three categories of early writing self-efficacy levels were decided, ranging from: Low (total score: 816), Moderate (total score: 17-24), and High (total score: 25-32). Figure 1 shows that after intervention, almost $60 \%$ of the experimental group students achieved an elevated level in early writing self-efficacy; they experienced vast improvement in early writing selfefficacy. The results showed the probability that children became more positive and believed in their writing ability, approached a writing task confidently, and persisted in completing the tasks given.

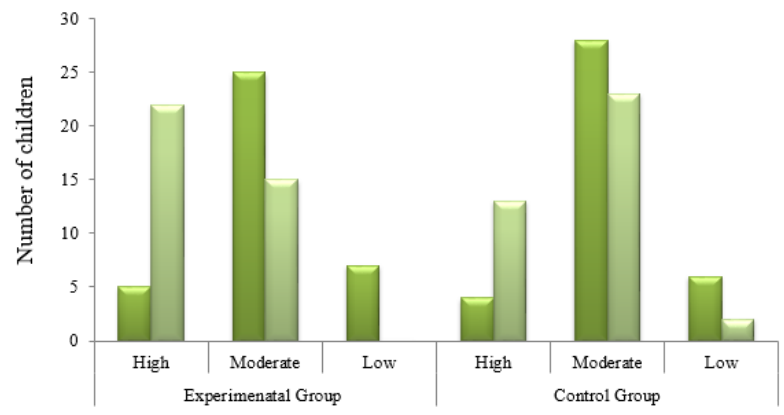

\begin{tabular}{|l|c|c|c|c|}
\hline Test & Level & Percent & Level & Percent \\
\hline Pre & Moderate & 67.6 & Moderate & 73.7 \\
$\square$ Post & High & 59.5 & Moderate & 60.5 \\
\hline
\end{tabular}

Figure 1 Level of early writing self-efficacy among preschool children in Malaysia

Past literature review pointed out that most of the teachers place very little focus on developing learners' self-efficacy in writing, including in the preschool classroom (Abbott, Berninger, \& Fayol, 2010; Ng \& Yeo, 2014). Overall, preschool teachers in Malaysia do not have a specific approach in teaching writing; instead, they often use copying and drilling as the main strategies in teaching writing (Samah, 2015; Ng \& Yeo, 2014). The results found that early writing self-efficacy can be enhanced through SRL intervention and should be taken should be taken seriously in early writing instruction.
The level of early writing performance among preschool children before and after intervention

Generally, preschool children in this study acquired limited competencies in mechanical writing skills and performed less in conveying meaning before SRL intervention. The early writing performance levels for experimental and control groups were lower than average, including all the aspects tested for early writing performance. The mean scores of total early writing performance for the experimental group $(M=9.76$, $\mathrm{SD}=6.29)$ and the control group $(\mathrm{M}=11.21, \mathrm{SD}=7.55)$ were lower than average, including all the aspects tested in early writing performance.

Before intervention, most of the preschool children performed less in mechanical writing skills and were unlikely to express their ideas explicitly and effectively. Some of them were only able to express one or two ideas, without elaboration. Figure 2 (i) and (ii) showed that the child wrote two ideas about "Lovely flower" and "New Year clothes". However, they were only able to narrate the ideas, not elaborately. The written texts also show that the preschool children in this study lacked mechanical writing skills, including capitalisation, formation of letters, etc.

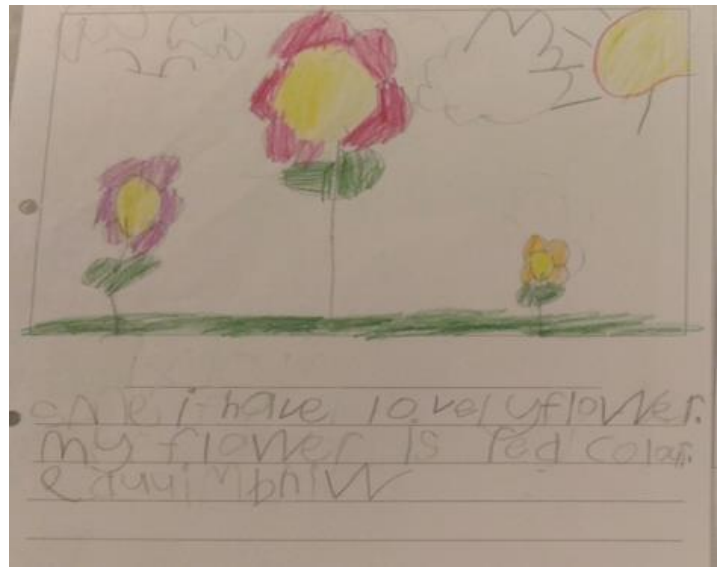

(i) 


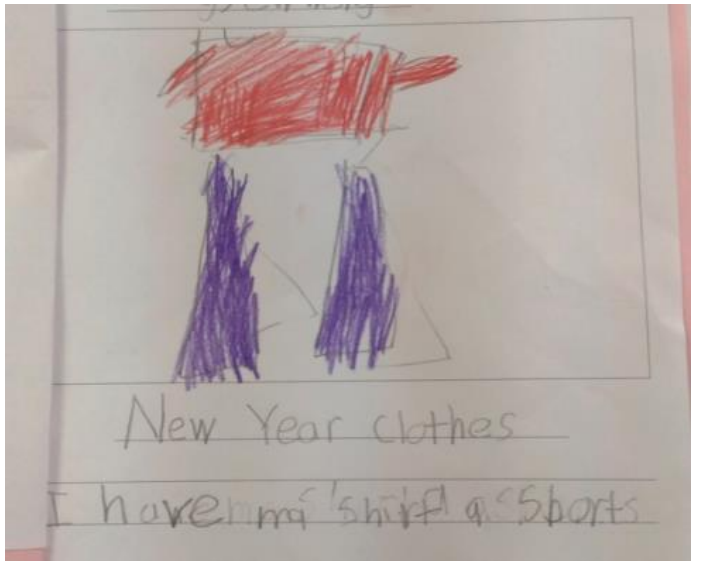

(ii)

Figure 2 Samples of written text among preschool children before intervention

After intervention, the experimental group increased their early writing performance to elevated levels during the post-test; this can be seen from Figure 3. The experimental group's children were able to express their ideas more effectively and creatively related to the topic chosen, with good mechanical writing skills. The text produced was longer and more complete.

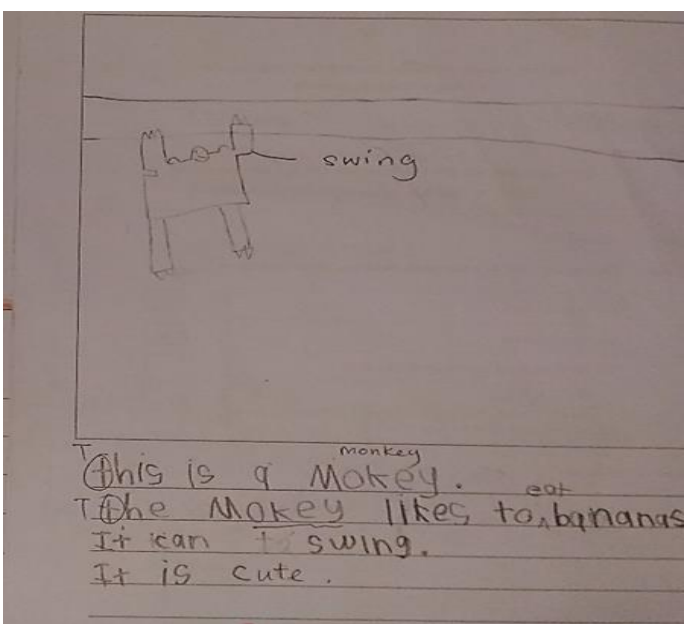

Child A

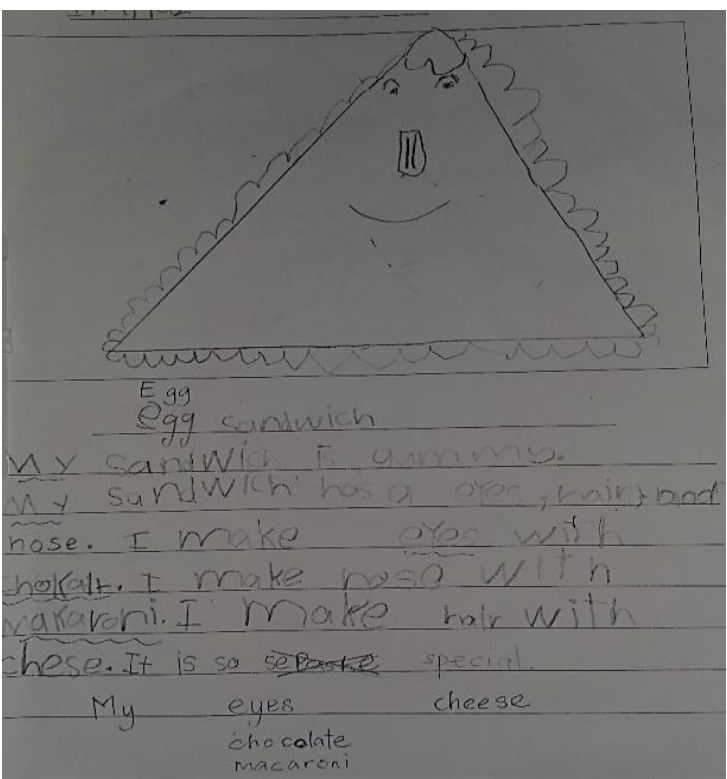

Child B

Figure 3 Samples of written text among preschool children after intervention

Despite the spelling and grammatical errors, the written texts produced were more interesting and comprehensive in terms of expression of ideas. For example, in Figure 3, Child A was able to describe the features of the animal (monkey) that he loves, and related the distinctive feature of the animal (monkey) to the reason he loves it with his imagination. Child $B$ wrote about his favourite food. He was able to tell the reason he loves a sandwich, and how and when he makes his own sandwich.

The use of SRL strategies among preschool children before and after intervention

This study found that overall use of SRL strategies among preschool children for both groups was low, only scoring 50-52 out of 104 (Table 3). The SRL strategies mostly employed were self-monitoring \& controlling, environmental controlling, and planning \& goal setting. However, after intervention, the experimental group was fond of engaging self-evaluation instead of environmental controlling. The experimental group children were able to self-evaluate their writing and their learning goals. 
Table 3. Descriptive Statistics of the Use of Self-regulated Learning Strategies for Experimental ( $\mathrm{N}=37)$ and Control Groups ( $\mathrm{N}=38)$

\begin{tabular}{llllllll}
\hline \multirow{2}{*}{ Domains } & \multirow{2}{*}{ Group } & \multicolumn{3}{c}{ Pre-test } & \multicolumn{3}{c}{ Post-test } \\
\cline { 2 - 7 } & & $M$ & $S D$ & $M d n$ & $M$ & $S D$ & $M d n$ \\
\hline Planning \& & Experimental & 1.89 & 0.81 & 1.60 & 3.17 & 0.68 & 3.20 \\
Goal setting & Control & 2.13 & 0.80 & 2.00 & 2.62 & 0.57 & 2.60 \\
\hline Task Strategies & Experimental & 1.66 & 0.79 & 1.30 & 1.66 & 0.79 & 1.30 \\
& Control & 1.64 & 0.52 & 1.70 & 1.64 & 0.52 & 1.67 \\
\hline Self-monitoring \& & Experimental & 2.16 & 0.82 & 2.00 & 2.92 & 0.58 & 3.00 \\
controlling & Control & 2.16 & 0.53 & 2.10 & 2.50 & 0.37 & 2.40 \\
\hline Environmental & Experimental & 1.94 & 0.56 & 2.00 & 1.91 & 0.61 & 2.00 \\
control & Control & 2.09 & 0.56 & 2.00 & 2.35 & 0.43 & 2.30 \\
\hline Self-evaluation & Experimental & 1.71 & 0.77 & 1.70 & 2.96 & 0.80 & 3.00 \\
& Control & 1.62 & 0.55 & 1.70 & 2.33 & 0.82 & 2.20 \\
\hline Total use of SRL & Experimental & 50.27 & 17.66 & 43.00 & 73.92 & 14.09 & 75.00 \\
& Control & 52.47 & 14.52 & 49.50 & 64.18 & 11.95 & 59.00 \\
\hline
\end{tabular}

This result confirmed that preschool children were able to learn and engage with self-regulated strategies, and the self-regulated learning skills can be enhanced with appropriate instruction, learning activities, pedagogical practices, and classroom environments (Pino-Pasternak, Basilio, \& Whitebread, 2014; Whitebread \& Basilio, 2012; Whitebread \& Coltman, 2010). There were five domains of SRL taught and tested in this study, namely planning and goal setting, task strategies, self-monitoring and controlling, environmental controlling and self-evaluation. SRSREWOF generated a profile with the five domains' scores and an overall score for the use of self-regulated learning strategies in early writing for Malaysian preschoolers.

The Effects of Intervention on Preschool Children's Early writing Self-efficacy

To confirm the effectiveness of $S R L$ intervention on early writing self-efficacy, Two-Way Repeated Measure ANCOVA was performed, and the results are in Table 4.

Table 4. Summary of Repeated Measure ANCOVA for Early Writing Self-Efficacy

\begin{tabular}{lccccc}
\hline $\begin{array}{l}\text { Source of } \\
\text { Variation }\end{array}$ & Df & MS & F & $\begin{array}{c}p- \\
\text { Value }\end{array}$ & $\eta 2$ \\
\hline Test & 1 & 5.008 & 0.687 & 0.410 & 0.009 \\
Test & 1 & 92.318 & 12.665 & 0.001 & 0.150 \\
Group & & & & & \\
\hline
\end{tabular}

To prove the effectiveness of SRL intervention on early writing self-efficacy, a pre-test and post-test were conducted. As shown in Table 4, the interaction between the Test and Group for early writing selfefficacy was statistically significant $\left(F_{(1,72)}=12.665 ; p=\right.$ $0.001, \eta^{2}=0.150$ ) for both groups across the times (preand post-test). The Cohen's effect size value $(d=0.84)$ suggested a high practical significance. In other words, preschool children from the experimental group showed a substantial increase in early writing self-efficacy after participating in a self-regulated learning intervention, and confirmed that by introducing the self-regulated learning strategies to the experimental group, the early writing self-efficacy was effectively enhanced in this current study (Anam \& Stracke, 2017; Bulut, 2017).

\section{Effects of Intervention on Preschool Children's Early writing Performance}

To prove the effectiveness of SRL intervention on early writing performance, a pre-test and post-test were conducted. Both of the experimental and control groups' children were required to write about "Lovely flower" during the pre-test, and "A special day" during the posttest. The written texts were scored by the two independent raters by using Early Writing Performance Scale developed in this study.

Two-Way Repeated Measure ANCOVA was applied to assess all the scores for three aspects: content, mechanical writing skills, and overall quality, and included the total performance in early writing performance between the groups and tests. The results are summarized in Table 5. 
Table 5. Summary of Repeated Measure ANCOVA for Early Writing Performance

\begin{tabular}{lllllll}
\hline $\begin{array}{l}\text { Source of } \\
\text { Variation }\end{array}$ & & Df & MS & F & $p$-Value & $\eta^{2}$ \\
\hline \multirow{3}{*}{ Test } & Content & 1 & 0.343 & 1.197 & 0.278 & 0.016 \\
& Mechanical writing skills & 1 & 2.568 & 0.919 & 0.340 & 0.013 \\
& Overall quality & 1 & 1.969 & 5.613 & 0.020 & 0.072 \\
& Total Performance & 1 & 12.900 & 2.693 & 0.105 & 0.036 \\
\hline \multirow{3}{*}{ Test * } & Content & 1 & 12.355 & 43.063 & $<0.001^{*}$ & 0.374 \\
Group & Mechanical writing skills & 1 & 240.465 & 86.091 & $<0.001^{*}$ & 0.545 \\
& Overall quality & 1 & 16.123 & 45.973 & $<0.001^{*}$ & 0.390 \\
& Total Performance & 1 & 530.711 & 110.801 & $<0.001^{*}$ & 0.606
\end{tabular}

* Significant at $p<0.005$

According to Table 5, the results for the interaction between the Test and Group for content were statistically significant $\left(F_{(1,72)}=43.063 ; p<0.001\right.$, $\left.\eta^{2}=0.374\right)$. In mechanical writing skills, a statistical significance for the interaction between the Test and Group $\left(F_{(1,72)}=86.091 ; p<0.001, \eta^{2}=0.545\right)$ was found. The results also indicated a statistical significance for the interaction between the Test and Group for Overall Quality $\left(F_{(1,72)}=45.973 ; p<0.001, \eta^{2}\right.$ $=0.390)$. The results indicated that the interaction between the Test and Group for total performance was statistically significant $\left(F_{(1,72)}=110.801 ; p<0.001, \eta^{2}=\right.$ 0.606). These results indicated that self-regulated learning intervention impacted all aspects in early writing performance and total performance among the preschool children in the experimental group. The effect size of the interaction effect in total early writing performance was considered high, with a Cohen's d value $=2.48\left(\eta^{2}=0.606\right)$, suggesting a high practical significance.

These results were in line with the outcomes of the studies identifying the contribution of SRL strategies in writing performance (Bulut, 2017; Graham, Gillespie, \& McKeown, 2013; Olinghouse \& Graham, 2009; Zimmerman \& Risemberg, 1997). Therefore, teaching SRL strategies to children can help them to be equipped with strategies to instil positive attitude and behaviours to perform better in their writing tasks.
Predictors for Early Writing Self-Efficacy and Early Writing Performance

To determine the predictors of SRL strategies for early writing self-efficacy and early writing performance, Standard Multiple Regression Analysis was performed. The results (presented in Table 6 ) suggested selfmonitoring \& controlling $(F(5,69)=17.934, p<.001)$, with an adjusted $R^{2}=0.534$, as a significant regression equation in predicting early writing self-efficacy. Planning and goal setting $(F(5,69)=12.706, p<0.001)$, with an adjusted $R^{2}=0.442$, was significant in predicting early writing performance for preschool children.

The findings show that the more children engaged in self-monitoring \& controlling strategies, including monitoring the writing process, managing effort and attention, seeking information, and seeking social help, the higher the early writing self-efficacy they achieved. This finding is aligned with the suggestion that writing requires elevated levels of cognitive engagement, intrinsic motivation, and self-monitoring activities (Schunk \& Zimmerman, 2007; Zumbrunn et al., 2010). When the children engage in self-monitoring and controlling behaviours, in terms of emotional and motivational beliefs, they will be able to manage their efforts by focussing or using a self-consequences strategy to motivate themselves for upcoming tasks.

Table 6. Standard Multiple Regression Analysis in Predicting Early Writing Self-Efficacy and Early Writing Performance

\begin{tabular}{|c|c|c|c|c|c|c|c|c|}
\hline \multirow{3}{*}{ Predictors } & \multicolumn{8}{|c|}{ Regression coefficients } \\
\hline & \multicolumn{4}{|c|}{ Early Writing Self-efficacy } & \multicolumn{4}{|c|}{ Early Writing Performance } \\
\hline & $\mathrm{B}$ & $\mathrm{SE}_{\mathrm{B}}$ & $\beta$ & p-value & $\mathrm{B}$ & $\mathrm{SE}_{\mathrm{B}}$ & $\beta$ & $p$-value \\
\hline $\begin{array}{l}\text { Planning \& goal } \\
\text { setting }\end{array}$ & 1.860 & 1.058 & 0.348 & 0.080 & 5.635 & 1.874 & $0.652^{*}$ & $<0.001$ \\
\hline \multirow{2}{*}{$\begin{array}{l}\text { Task strategies } \\
\text { Self-monitoring \& } \\
\text { controlling }\end{array}$} & 1.081 & 0.775 & 0.167 & 0.160 & -0.573 & 1.373 & -0.055 & 0.680 \\
\hline & 3.411 & 0.898 & $0.543^{*}$ & $<0.001$ & 0.939 & 1.590 & 0.092 & 0.560 \\
\hline $\begin{array}{l}\text { Environmental } \\
\text { controlling }\end{array}$ & -1.405 & 0.817 & -0.184 & 0.090 & 0.368 & 1.446 & 0.030 & 0.800 \\
\hline \multirow[t]{2}{*}{ Self-evaluation } & -0.987 & 0.983 & -0.153 & 0.310 & -0.221 & 1.741 & -0.021 & 0.890 \\
\hline & \multicolumn{4}{|c|}{$\begin{array}{l}\text { Adjusted } R^{2}=0.534 \\
F=17.934, p<0.001\end{array}$} & \multicolumn{4}{|c|}{$\begin{array}{l}\text { Adjusted } R^{2}=0.442 \\
F=12.706, p<0.001\end{array}$} \\
\hline
\end{tabular}


Planning and goal setting as strong predictors for early writing performance fit into the cognitive writing model, which stated that writing is a goal-directed activity (Costa et al., 2017; Hayes, 2012). According to the cognitive writing model, goals guide the writers throughout the writing process, where writers set and revise goals and sub-goals throughout the writing process, and finally enhance the writing performance. Self-regulated writers will assess or evaluate their personal achievements related to the expected goals or outcomes. If they failed to achieve their goals, they revised their goals and the strategies used in their writing task (Hayes, 2012). These findings paralleled some studies providing staunch support for the association between planning and early writing quality among the lower grade children (Graham et al., 2013; Olinghouse \& Graham, 2009). When children engaged with planning and goal setting, they tended to be more conscious in understanding their task requirements and planning their learning outcomes. They created better learning habits in goal setting and planning their writing, thus enhancing their writing performance (Dent \&
Koenka, 2015; Limpo \& Alves, 2013; Limpo, Alves, \& Fidalgo, 2014).

SRL strategies mostly employed by out-performing children pertaining to different contexts

Eight children from the experimental group were interviewed and observed in this study. The observation and interview data provided this study with rich information about how children used these strategies in their writing tasks within different contexts. Eleven strategies emerged from the data, including planning, goal setting, keeping records, self-monitoring writing process, seeking social help, seeking information, effort management, self-consequences, environmental controlling, memorising, and self-evaluation. The percentage of strategies suggested within different contexts was calculated and is shown in Table 7. The findings resulting from the interviews sessions showed that children use different strategies pertaining to different contexts in this study.

Table 7. Summary of the use Self-regulated learning Strategies during Early Writing

Context Self-regulated learning strategies

Assume your teacher discussed about a topic about "sport day" with Keeping records (50\%)

your class. You will have to write about it. Do you have a method to Memorising (37.5\%)

help you to remember what was discussed in class?

Your teacher asks you to write a short story about "My family" at Effort management (67.5\%)

home. How do you write? Do you have any particular method to help Seeking information (50\%)

you plan and write at home?

Seeking social help (50\%)

Planning (37.5\%)

Memorising (25\%)

Goal setting $(12.5 \%)$

Do you have any special method that you always use to complete Planning (87.5\%)

your writing task in class?

Self-monitoring writing process $(50 \%)$

Goal setting $(37.5 \%)$

Self-evaluation $(37.5 \%)$

Seeking information (37.5\%)

\begin{tabular}{ll}
\hline Sometimes our friends are playing, reading other books, talking or & Effort management $(100 \%)$ \\
running around...Do you have any special method to motivate & Environmental controlling (50\%) \\
yourself to complete your work under these conditions? & Self-consequences $(37.5 \%)$
\end{tabular}

How do you make sure your writing is always the best? $\quad$ Self-evaluation (100\%)

Planning $(62.5 \%)$

Goal setting $(37.5 \%)$

Self-monitoring writing rules $(25 \%)$

Seeking social help (25\%)

There were two to six strategies suggested by the children for handling early writing pertaining to each context. In the interview, children revealed that they set goals and planned appropriately to attain their goals in their writing task. In addition, effort management and self-evaluation were mostly suggested by the children when pursuing writing. All children mentioned that they engaged in controlling their effort, focus, and attention on their task, and it was important to make sure they could complete their work, especially in a poorlymotivated environment. All children also commented that self-evaluating is important for them to ensure skilful writing. These findings indicated that children applied certain strategies in certain contexts; for 
example, seeking information and seeking social help were mostly suggested for completing tasks at home. Self-evaluation was mostly used to help them in completing tasks at school and assure the quality of writing.

$S R L$ is a personal process and a passionate learning approach. It allows learners to learn according to their own ability and unique learning needs. When children planned their targeted goal according to their abilities and learning resources they have in hand, they feel more confident and willingly to write. Interview data revealed the reality that children experience and further explained the results produced by the quantitative data.

\section{CONCLUSIONS AND RECOMMENDATIONS}

Early writing is one of the important components in early literacy, and writing itself is a valuable tool for gathering and conveying information in the learning process (Graham, Gillespie, \& Mackweon, 2013; Miller, McCardle, \& Long, 2017; Puranik et al., 2014). Children use marks on paper and correspondence with meaning, and use writing when presenting their knowledge and understanding of the content they learned. Although preschool children in Malaysia lacked mechanical writing skills and presented their ideas less effectively, early writing performance of experimental group was increased to an elevated level after intervention. Previous studies suggested that prior to starting the writing process, good writers plan, set goals, and use knowledge specific to the writing task in hand to produce quality writing (Graham et al., 2013; Limpo, Alves, \& Fidalgo, 2014). This suggestion was proven in this study, where SRL intervention's effect on early writing performance was double that of instruction without intervention. Therefore, improving instruction in early writing by incorporating SRL strategies can help children to be equipped with strategies while instilling a positive attitude and behaviours for better writing performance (Gerde et al., 2015; Miller, McCardle, \& Long, 2017).

\section{REFERENCES}

Abbott, R. D., Berninger, V. W., \& Fayol, M. (2010). Longitudinal relationships of levels of language in writing and between writing and reading in grades 1 to 7. Journal of Educational Psychology, 102(2), 281-298.

Anam, S. \& Stracke, E. (2016). Language learning strategies of Indonesia primary school students: In relation to self-efficacy beliefs. System 60(2016), 1-10.

Bandura, A. (2012). Social cognitive theory In P. A. M. V. Lange, W. Kruglanski \& E. T. H. Thousand (Eds.), Handbook of theories of social psychology (Vol. 1, pp. 349-373). Thousand Oaks, CA.: Sage London.

Bingham, G. E., Quinn, M. F. \& Gerde, H. K. (2017). Examining early childhood teachers' writing practices: Associations between pedagogical supports and children's writing skills. Early Childhood Research Quarterly, 39, 35-46.
Bulut, P. (2017). The effect of primary school students' writing attitudes and writing self-efficacy beliefs on their summary writing achievement. International Electronic Journal of Elementary Education, 10(2), 281-285.

Costa, L. J., Ahmad, U., Edwards, C., Vanselous, S., Yerby, D.C., \& Hooper, S.R. (2017). The Writing Side. In Miller, B., McCardle, P. \& Long, R. (Eds). Teaching reading and writing: Improving instruction and student achievement (pp. 21-34), Baltimore, Maryland: Brooke.

Demirtas, V. Y. (2013). Self-regulation strategies of the six-year-old preschool children. International Journal of Academic Research, 5(2), 264-273. doi: 10.7813/2075-4124.2013/5-2/B.42

Dent, A. L., \& Koenka, A. C. (2015). The relation between self-regulated learning and achievement across childhood and adolence: A meta-analysis. Educ Psychol Rev., 28, 425-474. doi: 10.1007/s10648-015-9320-8

Diamond, A. (2016). Why improving and assessing executive functions early in life is critical. Executive function in preschool age children: Integrating measurement, neurodevelopment and translational research. Washington, DC: American Psychological Association.

Gerde, H. K., Bingham, G. E., \& Pendergast, M.L. (2015). Environmental and teacher supports to writing in classrooms. Early Childhood Research Quarterly, 31, 31-46.

Graham, S., Gillespie, A., \& McKeown, D. (2013). Writing: Importance, development, and instruction. Reading and Writing, 26(1), 1-15.

Hall, A. H., Simpson, A., Guo, Y., \& Wang, S. (2015). Examining the effects of preschool writing instruction on emergent literacy skills: A systematic review of the literature. Literacy Research and Instruction, 54(2), 115-134.

Hayes, J. R., \& Olinghouse, N. G. (2015). Can cognitive writing models inform the design of the common core state standards? The Elementary School Journal, 115(4), 480-497.

Hutchinson, L. R. (2013). Young children's engagement in self-regulation at school. University of British Columbia.

Jalaluddin, I. (2013). Predicting writing performance outcome via writing self-efficacy and implication on L2 tertiary learners in Malaysia. World Applied Sciences Journal. 26, 643-652.

Kim, J. A., \& Lorsbach, A. W. (2005). Writing selfefficacy in young children: Issues for the early grades environment. Learning Environments Research, 8, 157-175.

Limpo, T., \& Alves, R. A. (2013). Modeling writing development: Contribution of transcription and self-regulation to Portuguese students' text generation quality. Journal of Educational Psychology, 105(2), 401.

Limpo, T., Alves, R. A., \& Fidalgo, R. (2014). Children's high-level writing skills: Development of planning and revising and their contribution to writing 
quality. British Journal of Educational Psychology, 84(2), 177-193.

McClelland, M. M., C.Acock, A., Piccinin, A., Rhea, S. A., \& Stallings, M. C. (2013). Relations between preschool attention span-persistence and age 25 educational outcomes. Early Childhood Research Quarterly, 28(2), 314-324.

Mega, C., Ronconi, L., \& Beni, R. D. (2014). What makes a good student? How emotions, selfregulated learning and motivation contribute to academic achievement. Journal of Educational Psychology, 106(1), 121-131.

Metallidaou, P. (2010). Children's self-regulated learning profile in language and mathematics: The role of task value beliefs. Psychology in the Schools, 47(8), 776-788. doi: 10.1002/pits.20503

Miller, B., McCardle, P. \& Long, R. (2017). Teaching reading and writing: Improving instruction and student achievement. $10^{\text {th }}$ edition, Baltimore, Maryland: Brooke.

MOE. (2015). Malaysia Education Blueprint 2013-2025. Ministry of Education, Kuala Lumpur, Malaysia.

MOE. (2017). National Preschool Standard-Based Curriculum: Standard-Based Curriculum and Assessment Document Putrajaya: Ministry of Education Malaysia.

Ng, P. F., \& Yeo, K. J. (2014). Preschool Teachers' Beliefs and Practices on Early Literacy Instruction. Sains Humanika, 2(4).

Olinghouse, N. G., \& Graham, S. (2009). The relationship between the discourse knowledge and the writing performance of elementary-grade students. Journal of Educational Psychology, 101(1), 37.

Panadero, E. (2017). A review of self-regulated learning: Six models and four directions for research. Front. Psychology, 8, $422 . \quad$ doi: 10.3389/fpsyg.2017.00422

Pino-Pasternak, D., Basilio, M., \& Whitebread, D. (2014). Interventions and classroom contexts that promote self-regulated learning: Two intervention studies in United Kingdom primary classrooms. PSYKHE 2014, 23(2), 1-13. doi: 10.7764/psykhe.23.2.739

Puranik, C. S., Al Otaiba, S., Sidler, J. F., \& Greulich, L. (2014). Exploring the amount and type of writing instruction during language arts instruction in kindergarten classrooms. Reading and Writing, 27(2), 213-236.

Samah, S. I. S. A., Majzub, R., \& Mahamod, Z. (2015). Teaching Writing in Preschool Classroom. Journal of Applied Research in Education, 19, 50-59.

Schunk, D. H., \& Zimmerman, B. J. (2007). Influencing children's self-efficacy and self- regulation of reading and writing through modeling. Reading and Writing Quarterly, 23, 7-25.

Teng, L. S., \& Zhang, L. J. (2016). A questionnairebased validation of multidimensional models of self-regulated learning strategies. The Modern Language Journal, 100(3), 674-701.
White, M. C., \& DiBenedetto, M. K. (2015). Selfregulation and the common core: Application to ELA standards: Routledge.

Whitebread, D., \& Basilio, M. (2012). The emergence and early development of self-regulation in young children. Profesorado, 16(1), 15-33.

Whitebread, D., Coltman, P., Pasternak, D. P., Sangster, C., Grau, V., Bingham, S., Demetriou, D. (2009). The development of two observational tools for assessing metacognition and selfregulated learning in young children. Metacognition and learning, 4(1), 63-85.

Zimmerman, B. J. (2013). From cognitive modelling to self-regulation: A social cognitive career path. Educational Psychologist, 48(3), 135-147.

Zimmerman, B. J., \& Risemberg, R. (1997). Becoming a self-regulated writer: A social cognitive perspective. Contemporary educational psychology, 22(1), 73-101.

Zimmerman, B. J., \& Schunk, D. H. (2012). Selfregulated learning and academic achievement: Theory, research, and practice: Springer Science \& Business Media.

Zumbrunn, S., Bruning, R., Kauffman, D., \& Hayes, M. (2010). Explaining determinants of confidence and success in the elementary writing classroom. Paper presented at the annual meeting of the American Educational Research Association, Denver, CO. 